\title{
PHYSIOLOGICAL AND HISTOCHEMICAL STUDIES ON THE LAND SNAIL, MONACHA CARTUSIANA IN SHARKIA GOVERNORATE
}

\author{
ISMAIL, SH.A. ${ }^{1}$, A.A.RASHED ${ }^{2}$, F.M.ABOU-SENNA ${ }^{2}$ and M. ABED ${ }^{1}$ \\ 1. Plant Protection Research Institute, Agric. Res. Center Dokki, Giza, Egypt \\ 2. Department of Zoology, Faculty of Science, Al Azhar University, Cairo, Egypt
}

(Manuscript received 3 June 2012)

\begin{abstract}
Physiological and histochemical studies were conducted on Monacha cartusiana snail, in order to determine some physiological and histochemical aspects during active and aestivation periods. Results of these studies showed reduction of the percentage of glucose in aestivation periods compared with the period of activity, where the concentration of glucose in the activity revealed 52.63 $\mathrm{mg} / \mathrm{dL}$, compared with an average concentration in aestivation, reaching $16.16 \mathrm{mg} / \mathrm{dL}$. Regarding the concentration of protein, it observed a decrease in aestivation period compared with activity period, where it reached $3.39 \mathrm{~g} \mathrm{/} \mathrm{dL}$ in the activity period compared with $1.9 \mathrm{~g} / \mathrm{dL}$ in aestivation. In case of urea the opposite results were recorded, where the urea concentration in the period of activity was $5.97 \mathrm{mg} / \mathrm{dL}$ compared with $7.89 \mathrm{mg} /$ $\mathrm{dL}$ in aestivation. The results of histochemical studies indicated the presence of large amounts of carbohydrates in the cells of the digestive gland as well as in the cells of foot in the previous of aestivation. Moreover the study showed that the snail consumed large amounts of carbohydrates during aestivation period.
\end{abstract}

\section{INTRODUCTION}

Terrestrial molluscs has become one of the serious pests in most of world countries especially those with moist or rainy climates, they are vegetarian and feed on a wide variety of plant parts both wild and cultivated that including field vegetable and fruit crops as well as ornamental plants (Godan, 1983). In Egypt, until 1980, land snails were considered as dangerous crop pests and cause effective damage in the northern governorates. In Sharkia Governorate the land snail, Monacha cartusiana reported a relatively high occurrence and population density on economic crops (Ismail, 1997). Snails survive many months without food and water under aestivation. The aestivated snails draw on their reserve of fat and glycogen at much reduced rate (Akinnusi, 1998). Histochemical investigations (Stickle, 1971 and Veldhuijzen and Van Beek, 1976) postulated that many molluscs which store glycogen in large amounts were noticed to utilize it during starvation period as a primary source of energy. According to (Beddiny 1979) carbohydrates were the first materials in the digestive 
gland in the two fresh water snails Helisoma duryi and Physa acuta to be used during starvation. Haemolymph composed of water, inorganic salts (mostly $\mathrm{Na}, \mathrm{Cl}, \mathrm{K}, \mathrm{Mg}$ and $\mathrm{Ca}$ ) and organic compounds (mostly carbohydrates, proteins and lipids) (Burton, 1965). There are limits to the duration of aestivation that can be tolerated by land snails and mortality eventually increases as aestivation is prolonged (Rees and Hand, 1993). Therefore, this study investigated the effect of aestivation period on glucose, total protein and urea levels in haemolymph and the localization of carbohydrate in digestive gland and foot of the land snail, Monacha cartusiana during active period and various period of aestivation. The aim of this study to determine some physiological and histochemical aspects during activity and aestivation periods.

\section{MATERIALS AND METHODS}

\section{I: Physiological studies:-}

This study was conducted to determine the concentration of glucose, protein and urea during the period of activity in different periods of aestivation (early and mid, as well as at the end of aestivation) found in Monacha cartusiana snail haemolymph. For this purpose, 30 adult snails were collected from heavy infested field at Sharkiat Mubasher village, Al-Ibrahimia country, Sharkia Governorate and then transferred to laboratory before each period of estimation. The period of estimation was divided as following: - active season (March, 2010) and in course of dormancy in the beginning of aestivation (June), mid of aestivation (August) and in the end of aestivation (October). According to Bezerra et al. (1997) the snails shell was cleaned with a paper towel and the haemolymph then collected by making a pierce just above the level of the pericardial cavity, and then a fine micropipette inserted carefully through a tiny hole and for aspiration of haemolymph. One $\mathrm{ml}$ of haemolymph was obtained from 30 snails in each period. The collected haemolymph was centrifuged at 1000 round per minute (rpm) for 10 minutes in order to precipitate haemocytes and cellular debris. The resulting supernatant was used in the laboratory analysis for measurement levels of glucose, total protein and urea according to Jacobs and vanDenmark (1960).

\section{II: Histochemical studies:-}

The present work was carried out to examine the carbohydrate moiety content in the digestive gland and foot snails such as the stage of normal nutrition compared to the one that entered in the stage of aestivation. Snails were collected from the same field mentioned previously at three different times (In active snail (prior to aestivation), in mid of aestivation and at the end of aestivation). The gastropods mass 
were carefully cleaned with a wet piece of cotton to clean the shell. Then gastropod mass were individually minced and washed several time in invertebrate saline $(0.7 \%)$ to remove mucus debris and pieces of broken shells, then fixed in alcoholic Bouin solution for 2 hours. To reveal the effect of aestivation on glycogen content of muscular tissue and hepatopancreas, sections were stained with periodic acid Schiff (PAS). Sections were then oxidized in $1 \%$ periodic acid for 5 minutes, washed in running tap water for 3 minutes then stained in Schiff reagent for 15 minutes. Sections were washed for 10 minutes in running tap water, dehydrated and then mounted according to Pearse (1972).

\section{RESULTS AND DISCUSSION}

\section{I: Physiological studies:-}

The effects of active and aestivation periods on some hemolymph content as glucose, total protein and urea for $M$. cartusiana snail were determined under laboratory conditions. Data presented in Table (1) and Fig (1\&2) revealed that glucose and total protein recorded high levels during active period compared with mean of levels during aestivation where recorded $52.63 \mathrm{mg} / \mathrm{dl}$ and $16.16 \mathrm{mg} / \mathrm{dl}$ for glucose, 3.39 and $1.90 \mathrm{~g} / \mathrm{dl}$ for total protein, respectively. Regarding the values of glucose and total protein during aestivation, higher values were recorded at the beginning of aestivation compared with low values at the end of aestivation where recorded 26.03 \& $8.46 \mathrm{mg} / \mathrm{dl}$ for glucose and $2.23 \& 1.36 \mathrm{~g} / \mathrm{dl}$, respectively.

Interestingly, serum urea exhibited an increase level from the beginning of aestivation until the end of aestivation showing 3.53 and $10.37 \mathrm{mg} / \mathrm{dl}$, respectively. Regarding general mean of the three components, it gave $1.9 \mathrm{~g} / \mathrm{dl}$ for total proteins and $16.16,7.89 \mathrm{mg} / \mathrm{dl}$ for glucose and urea, respectively. Generally, it could be concluded that glucose and total proteins compounds were decreased during aestivation, while urea was increased during aestivation. These results are agree with those of Friedl, (1975) who indicated that starved snails used protein as an energy source during starvation. Rees and Hand, (1993) found that in Oreohelix strigosa and O. subrudis snails polysaccharide was catabolized early in aestivation, and protein was the primary metabolic substrate after polysaccharide reserves were depleted. Moreover lipid was catabolized at a low rate throughout aestivation. Regarding urea and purine bases accumulated during aestivation as a result of protein catabolism. Abo-Naser, (1998) revealed that higher values in urea concentration found in starved snails due to the increase in urea cycle activity. Shahawy, (2005) reported that 
glucose concentration and total protein in $M$. cantoina snail decreased in starvation compared with urea which increased in starvation.

In contrast of these result, Da Silva and Zancan, (1994) found that in Megalobulimus oblongus snail, the haemolymph glucose levels were higher in summer than in other seasons. The glycogen content of the hepatopancreas, muscle and mantle was constant throughout the year, except in winter when lower values were found. Glycogen metabolism seems to constitute the source of energy substrate during winter.

Table 1. Biochemical parameters of $M$. cartusiana snail during active period and aestivation period.

\begin{tabular}{|l|c|c|c|c|c|}
\hline \multirow{2}{*}{ parameters } & \multicolumn{1}{|c|}{$\begin{array}{c}\text { During active } \\
\text { period }\end{array}$} & \multicolumn{4}{|c|}{ During aestivation } \\
\cline { 2 - 6 } & $\begin{array}{l}\text { Active } \\
\text { snails(control) }\end{array}$ & $\begin{array}{l}\text { Beginning of } \\
\text { aestivation }\end{array}$ & $\begin{array}{l}\text { Mid of } \\
\text { aestivation }\end{array}$ & $\begin{array}{l}\text { End of } \\
\text { aestivation }\end{array}$ & Mean \\
\hline Glucose (mg/dl) & 52.63 & 26.03 & 13.99 & 8.46 & 16.16 \\
\hline $\begin{array}{l}\text { Total proteins } \\
\text { (g/dl) }\end{array}$ & 3.39 & 2.23 & 2.16 & 1.36 & 1.9 \\
\hline $\begin{array}{l}\text { Urea } \\
\text { (mg/dl) }\end{array}$ & 5.97 & 3.53 & 9.77 & 10.37 & 7.89 \\
\hline
\end{tabular}

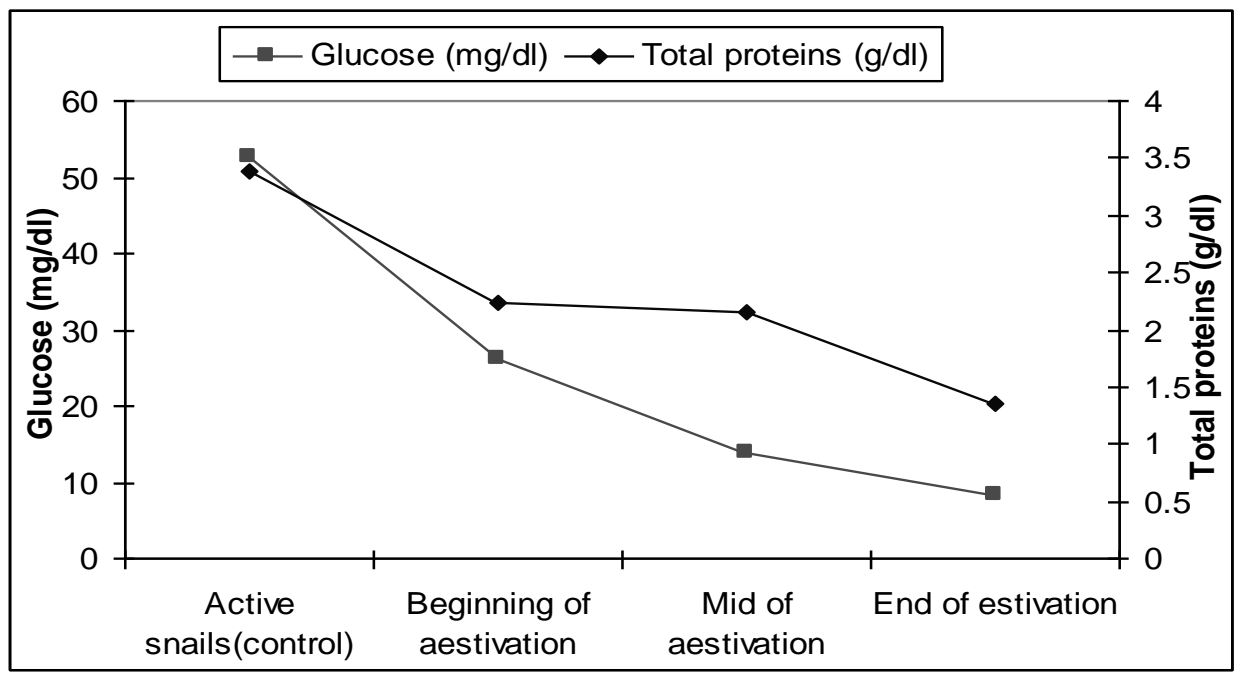

Fig 1. Glucose and Total protein concentration during active period and aestivation period in M. cartusiana 


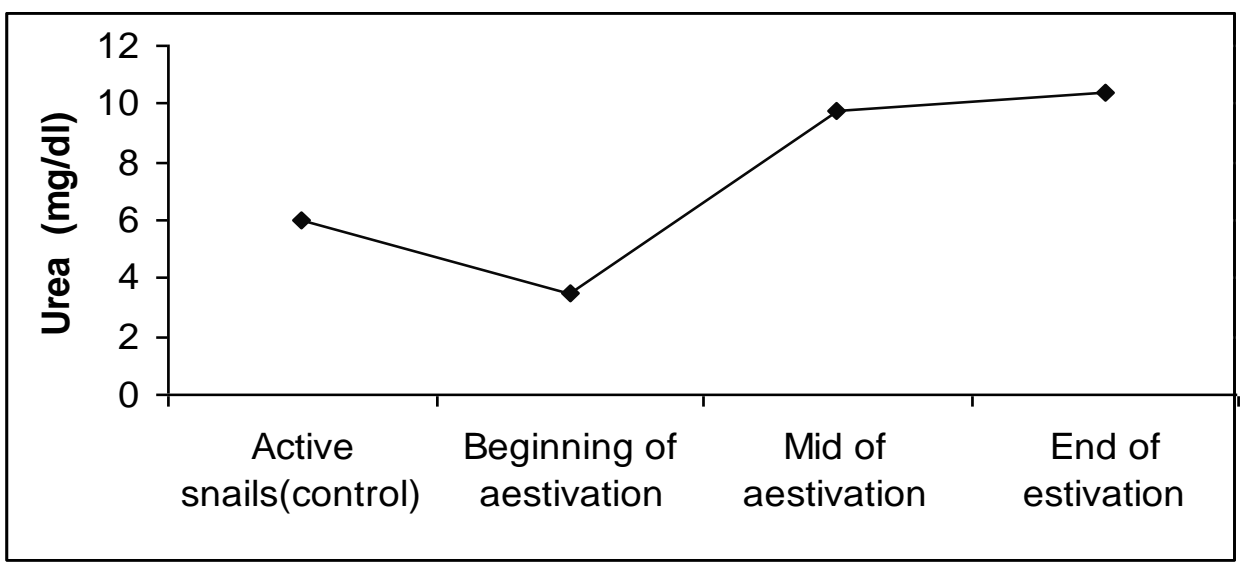

Fig 2. Urea concentration during active period and aestivation period in M. cartusiana.

\section{II: Histochemical studies:-}

Foot and hepatopancreas of $M$. cartusiana snail were stained with heamotoxylin, eosin and periodic acid Shiff (PAS) for the detection on the carbohydrate content. Experiments results can be summarized in Figs A-F as follows:

\section{A-Hepatopancreas:}

Normally, the digestive gland is a large deeply brown colored structure occupying the visceral hump of the snail. It consists of two unequal lobes where the anterior part is smaller than the posterior one. The whole gland is enclosed by a sheath of connective tissue and each lobe is formed of branching tubules which is surrounded by a thin layer of circular muscle fibers. The cells were arranged around an irregular lumen and these cells divided into digestive cells, excretory cells and calcium cells. The digestive cells are formed of columnar or cub shaped the cells resting on a thin basement membrane. The excretory cells less abundant than digestive ones they are pyramidal and shorter than digestive cells. Calcium cells low in number and short present in epithelium base pyramidal in shape.

\section{In active snail (prior to aestivation):}

The PAS stained sections showed that, the digestive cells are characterized by the presence of intensively or deeply stained coarse glycogen granules located mainly in both the apical and basal region of the cells. The hepatopancreatic acini are filled with muco poly sacchride (MPS). The secretory bodies exhibit a strong reaction towards PAS. The irregular lumens are normal in size as illustrated in Plate, $(1 \mathrm{~A})$. 


\section{In mid of aestivation:}

Sections stained with PAS showed that the glycogen granules occupied the apical portion of the digestive cells and showed strongly stained granules of carbohydrate. The basal regions are moderately colors fine particles Plate, (1B).

\section{At the end of aestivation:}

The digestive cells were faintly stained with PAS and glycogen was displayed as moderately coarse granules in the apical portions of cells and fine particles in the basal portion. The excretory bodies are occupied with weakly PAS fine granules. The lumens were reducing in size Plate, $(1 \mathrm{C})$.

\section{B- Foot:}

The foot is essential powerful muscle, yellow in color, lying beneath the visceral hump. It consists of an outer epithelial covering represented the mantle and an inner layer which is dermis consisting of dense fibrous connective tissue. The epithelium is composed of a single layer of two type of columnar to cuboidal shaped cells, and ciliated cells distinguished by their apical cilia on surface. It has numerous secretory cells. The dermis is formed of muscular and collagen fibers interweaved in all directions among compact reticular connective cells and abundant circular and oval amebocytes. The muscle cells of the integument are spindle shaped, uninucleate and unstriated. Muscle cells usually connect directly with the collagenous connective tissue surrounding them, rather than forming muscle-to-muscle connections. Muscle cells contain mitochondria in varying numbers, and stored glycogen is present reflecting the cell's metabolic demands.

\section{In active snail (prior to aestivation):}

The PAS preparations showed that, the foot is characterized by the presence of deeply stained glycogen granules concentrated on the outer layer (epidermis layer) and inner layer of foot (dermis and muscle layer) Plate, (1D).

\section{In the mid of aestivation:}

The PAS preparation showed mild aggregated of glycogen granules at the dermis layer of foot. The glycogen granules less than that found in active snail Plate, (1E).

\section{In end of aestivation:}

The PAS preparation showing very little of glycogen granules aggregated at the edge of foot. The Muscle fibers were free from glycogen granules Plate, (1F).

The effects of aestivation on carbohydrate content in foot and heapatopancreas of land snail $M$. cartusiana have been reviewed by many authors. The obtained results ran parallel with Runham, (1975) found that the digestive gland is the largest organ in the body of terrestrial gastropods. It consists of two lobes 
communicating with the stomach via large ducts. Recently, Sharaf, (2009) revealed a pronounced decline of carbohydrates in the digestive gland cells of snail after starvation. Severe decline in carbohydrate content was observed especially after 30 days of starvation. Moreover, protein inclusions have exhibited week stain ability in the digestive gland cells of these snails as a consequence of starvation.

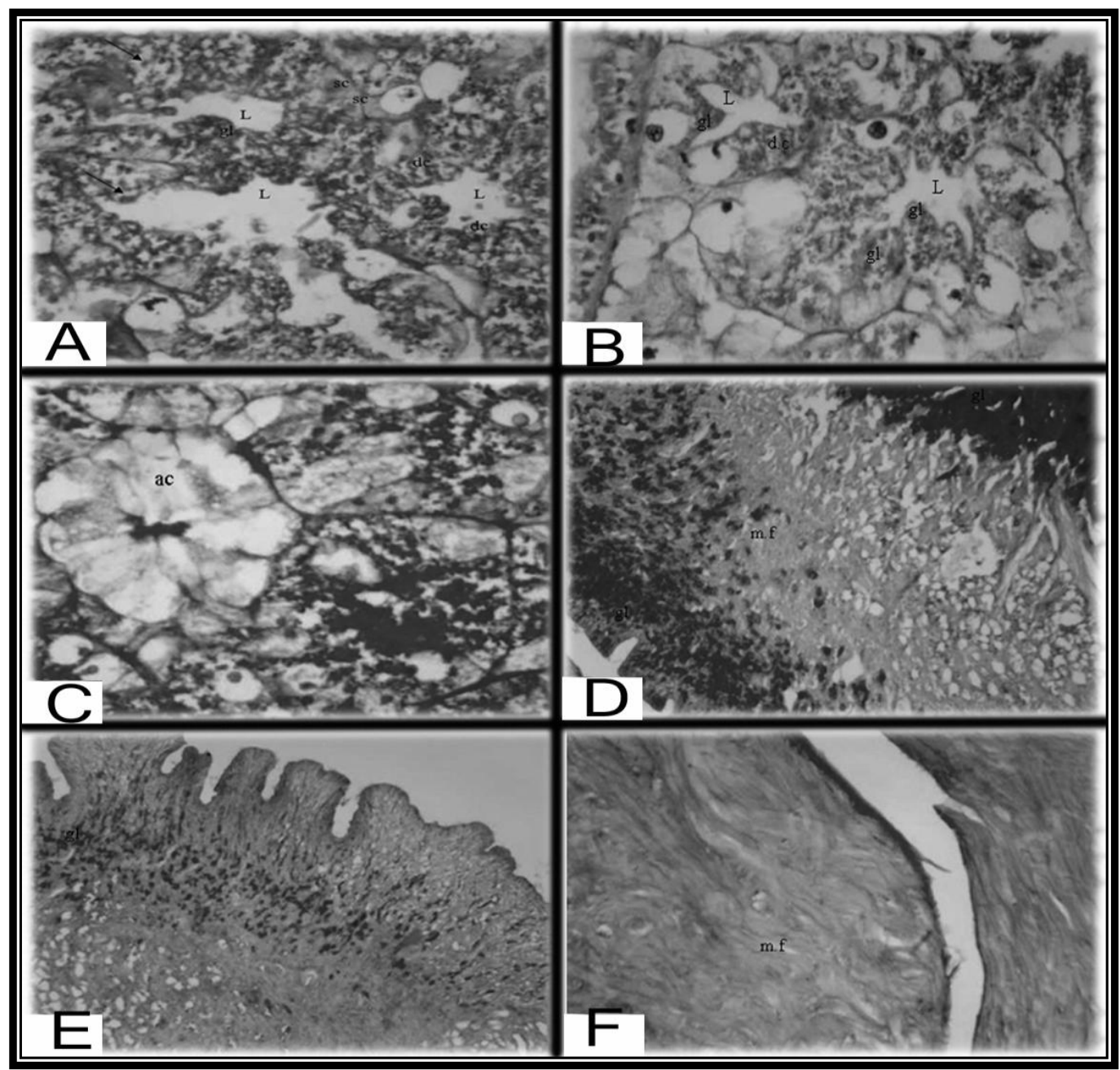

Fig (A): Showing hepatopancreatic acini rich in granules of MPS (actively feeding snails). L. =lumen, dc. $=$ digestive cell, gl.= glycogen granules, $\mathrm{sc} .=$ secretory cells. X100.

Fig (B): Revealing the hepatopancreas stained with PAS. Note that pyramidal cells are mildly filled with glycogen granules ( $\mathrm{gl}$ ) with relatively small leumens (L).X100.

Fig (C): Showing hepaopacreatic acinus (ac) nearly devoides of glycogen granules and digestive enzymes at the end of aestivation, PAS. X100. 
Fig (D): Showing glycogen granules ( $g l$ ) concentrated at the periphery of foot (dark pinky color), and muscle fibers (mf), PAS.X40.

Fig (E): Showing head foot muscles at the mid time of aestivation showing mild aggregates of glycogen granules at the periphery of head foot, PAS.X40

Fig (F): Showing very little of glycogen granules aggregated at edges of head foot. Note the gaps found between bundles of muscle fibers (mf), PAS.X10

\section{REFERENCES}

1. Abo-Naser, N. F. 1998. Studies on the effect of some food items on the biology of Biomphalaria alexandrina snails and their laboratory maintenance. M.Sc. Thesis, Fac. Agric., Tanta Univ., 94 pp.

2. Akinnusi, O. 1998. A practical approach to backyard snail farming. Nig. J. Anim. Prod., 25: 193-197.

3. Beddiny, E.A. 1979. Comparative studies on the effects of starvation on the structures and function in the digestive glands of Heliosoma duri and Physa acuta. J. Egypt Soc. Parasitol. 9 (2), 275-290.

4. Bezzerra, J.C.B., Becker, W. And Ezelck, U. 1997. A comparative study of the organic acid content of the hemolymph of Schistosoma mansoni- Resistant and susceptible strains of Biomphalaria glabrata. Mem. Inst. Oswaldo. Cruz., $92(3): 421-426$.

5. Burton, R.F. 1965. Na, K, Mg in the blood of the snail Helix pomatia. Physiol. Zool., 38: 335-342.

6. Da Silva, R.S.M. and Zancan, D.M. 1994. Seasonal variation of the carbohydrate and lipid metabolism in a land pulmonate gastropod, Megalobulimus oblongus. Comp. Biochem. Physio., 108 A: 337-341.

7. Friedl, F.E. 1975. Nitrogen excretion in Lymnaea stagnalis-an effect of ingested carbohydrate. Comp. Biochem. Phsiol., 52A: 377-379.

8. Godan, D. 1983. Pest slugs and snails, biology and control. Springer-Verlag Berlin, Heidelberg., 445 pp.

9. Ismail, Sh.A., 1997. Ecology, biology and control of certain terrestrial snails infesting some vegetables and field crops in Sharkia Governorate. Ph.D. Thesis, Fac. Agric., Zagazig Univ., 130pp.

10. Jacobs, N.J. and Vandenmark, P.J. 1960. Colorimetric method for determination of triglycsrides. Arch Biochem.Biophys., 88:250-255.

11. Pearse, A.G. E. 1972. Histochemistry theoretical and applied $3^{\text {rd }} 1518 p p$ London. A.G. Church. 
12. Rees, B.B. and S.C. Hand. 1993. Biochemical correlates of aestivation tolerance in the Mountain snail Oreohelix (Pulmonata: Oreohelicidae). Biol. Bull., 184: 230-242.

13. Runham, N.W. 1975. Alimentary canal pp. 53- 106 in fretter, v. and peake J. eds pulmonates vol. (1) functional anatomy and physiology, London Academic pres.

14. Shahawy, M.A. 2005. Biological and histological studies on the land snail Monacha cantiana (Montage) and its control at Kafer EL-Sheikh region. Ph.D. Thesis, Fac. Agric., Tanta Univ., 128 pp.

15. Sharaf, H.M. 2009. Histochemical changes of carbohydrate and protein contents in the digestive gland cells of the land snail Monacha cartusiana following starvation. Saudi. J. Biol. Sci., 16: 51-55.

16. Stickle, W.B. 1971. The metabolic effect of starving Thais lamellosa immediately after spawning. Comp. Biochem. Physiol. 40A, 627- 634.

17. Veldhuijzen, J.P. and Van Beek, G. 1976. The influence of starvation and of increased carbohydrates intake on the polysaccharide content of various body parts of the pond snail Lymnaea stagnalis. Neth. J. Zool. 26 (1), 106-118. 


\title{
دراسات فسيولوجية وهستوكميائية علي القوقع الارضي موناكا كارتوسيانا في محافظة الشرقية
}

\author{
شحاتة أحمد علي إسماعيل'، عمرو عبدالحئيم راثد²، \\ فكري محمد أبو سنة2 ، محمد عابد 1

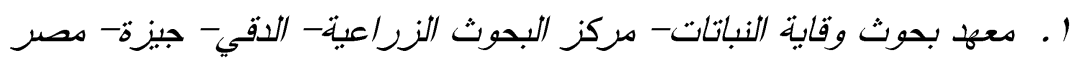

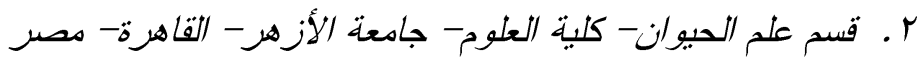

أجريت بعض الدراسات الفسيولوجية والهستوكيائية علي قوقع الموناكا كارتوسيانا بهدف تعيين

بعض النواحي الفسيولوجية والهستوكميائية أثناء النشاط وفنرات البيات الصيفي. أوضحت النيات النتائج

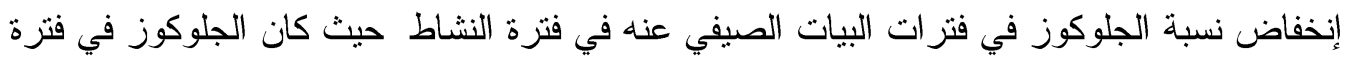

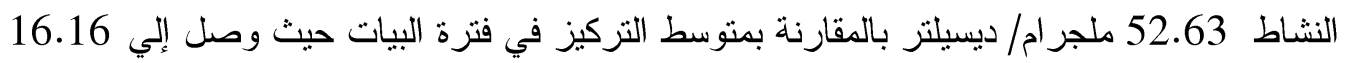

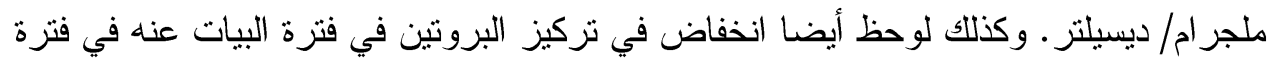

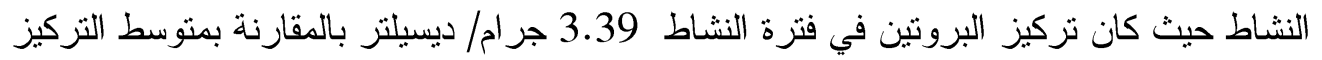

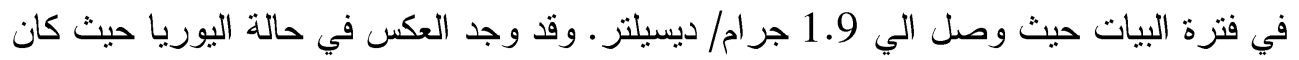

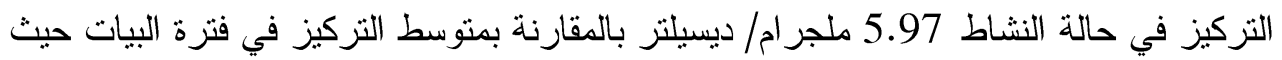
وصل الي 7.89 ملجر ام/ ديسيلنز.

بالنسبة للار اسات الهستوكميائية بينت النتائج وجود كميات كبيرة من الكربو هيدرات في خلايا

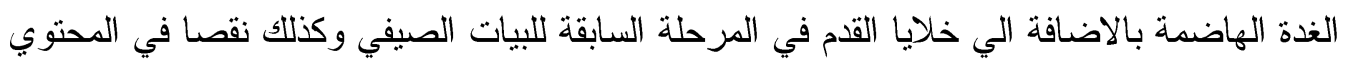

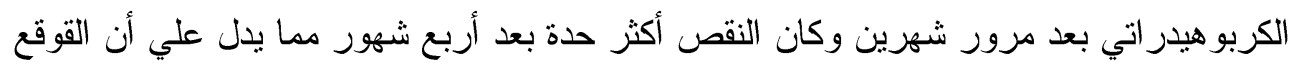

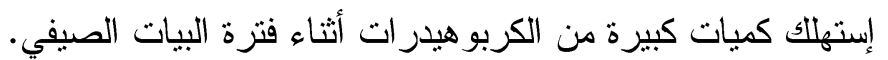

